\title{
INFLUENCE OF FOLLICLE SIZE ON QUALITY OF CUMULUS OOCYTE-COMPLEXES AND CONCENTRATION OF STEROIDS OF FOLLICULAR FLUID IN BUFFALO
}

Heleil,B'. ; Torner, $\mathrm{H}^{2}$; Mahmoud, Sh. $\mathrm{A}^{3}$; Alm. $\mathrm{H}^{2}$; and Fattouh.E.M ${ }^{\prime}$

'Dept. of Theriogenology, Faculty of Veterinary Medicine, Tanta University..

${ }^{2}$ Research Instit.Biology of Farm Animals, 18196 Dummerstorf, Germany.

${ }^{3}$ Dept. of Physiology, Faculty of Veterinary Medicine, Tanta University

\begin{abstract}
The aim of the present study was to investigate the effect of follicle size on the buffalo cumulus oocyte complexes (COCs) morphology, chromatin configuration, level of apoptosis in cumulus cells, and concentration of progesterone and estradiol-17 $\beta$ in buffalo follicular fluid of different follicle size. Visible follicles were carefully isolated and classified according to their size into 3 categories $<3 \mathrm{~mm}$ (2-3 $\mathrm{mm}), 3-5$ $\mathrm{mm}$ and $>5 \mathrm{~mm}(5-8 \mathrm{~mm})$. A total of 295 COCs were recovered from the previous three follicle categories; COCs were classified according to number and compactness of cumulus layers. Good quality compact COCs which used for IVM, which mostly obtained from follicles $<3$ and $3-5$ (56-7\%, 57.1) in comparison to $34.3 \%$ from large follicle.

The chromatin configuration at the time of recovery in oocytes derived from $<3 \mathrm{~mm}$ and $3-5 \mathrm{~mm}$ follicles arrested at the germinal vesicle stage, $60 \%$ and $70.8 \%$ respectively. On the other hand, highest proportion of oocyte in resumption of meiosis were found in oocyte obtained from large follicle (77.8\%) Vs $40 \%$ and $29.2 \%$ from $<3 \mathrm{~mm}$ and $>3-5 \mathrm{~mm}$ follicle respectively.
\end{abstract}

There was a connection of cumulus morphology, chromatin configuration at the time of recovery and the follicle size.On the other hand no significant differences in maturation capacity (metaphase2) of COCs derived from different follicles diameter.

$\overline{\text { Kafr El-Sheikh Vet. Med. J. Vol. } 1 \text { No. } 1 \text { (2003) }}$ 
Apoptosis of cumulus at time of recovery decreased with increasing the follicle size, but this difference was not significant (0.9, 0.6,0.2). After $24 \mathrm{hr}$. IVM, an increase in apoptosis was observed in cumulus cells from all follicle size with significant $(P<0.05)$ increase in cumuli derived from $3-5 \mathrm{~mm}$ follicles compared to $<3$ and $>5 \mathrm{~mm}$ follicles $(24.4 \mathrm{Vs} 4.7,3.5)$

Concentration of progesterone $(\mathrm{ng} / \mathrm{ml})$ in buffalo follicular fluid was not influenced by follicle size, while concentration of estradiol-17 $\beta(\mathrm{ng} / \mathrm{ml})$ was significant higher in follicle 3-5, >5 $\mathrm{mm}$ (782 \pm 67 and $788 \pm 67$ respectively) in comparison to follicular fluid from $<3 \mathrm{~mm}$ follicles (682 \pm 67 ).

Keywords:buffalo, oocyte, follicle size,apoptosis, progesterone, estradiol-17 $\beta$.

\section{INTRODUCTION}

The world population of buffaloes has been estimated at 130-150 million (one eight of the cattle population). Buffalo has greater potential animal protein than cattle in more than 40 developing countries mostly in tropical and subtropical regions. Buffalo continues to be neglected because of its low reproduction capacity. Application of embryo transfer technology to buffalo has been limited success (Misra et al., 1991).

In vitro maturation and fertilization technology is now being used for production of embryo from ovaries obtained from abattoir. This practice will not only increase the buffalo population but will also help to rescue the precious germ plasm that is lost by slaughter. Preliminary results obtained by Totey et al.,(1992,1996), on buffalo in vitro maturation and fertilization has shown poor maturation, fertilization and development of rates. There is still clear difference between ova obtained from in vivo maturation and oocyte culture in vitro (Sirard and Blondin, 1996). In general oocytes obtained from slaughterhouse matured and fertilized in vitro develop to about $30 \%$ blastocyst rate. This limited success may be attributed to heterogeneous population of oocytes obtained from this follicle population (DeLoos et al., 1989).

$\overline{\text { Kafr El-Sheikh Vet. Med. J. Vol. } 1 \text { No. } 1 \text { (2003) }}$ 
The size of the follicle seems to be an important factor in the selection of potential oocytes (Pavlok et al.,1992,1993,1997). Moreover, the meiotic competence of oocytes is closely related to follicular dimension (Tan and Ku, 1990, Lonergan et al., 1992; Yang et al., 1998; Hageman, 1999). Oocytes originating from follicles smaller than $2 \mathrm{~mm}$ in diameter could not develop beyond the 8-cell stage. Whereas oocytes obtained from follicles measuring 2-4 $\mathrm{mm}$ and $>4 \mathrm{~mm}$ possessed comparable developmental competence (Tan and Ku, 1990). Heleil, (1999) and Heleil et al., (2001) reported that oocytes from follicles larger than $3 \mathrm{~mm}$ in diameter have better developmental competence to morula/blastocyst stage after IVM/IVF than those form smaller follicles.

Many follicles with diameter $>1 \mathrm{~mm}$ undergoes atresia (Kruip and Dielman, 1982; Driancourt, 1991), resulting in heterogeneous follicle population. The first signs of atresia are manifested by degeneration of the granulosa cells, whereas the oocyte affected in the very last stages of atresia (Kruip and Dielman, 1982). Recent studies of morphologically atretic follicles from several species indicate that follicular degeneration can be explained in a part, by apoptotic death of granulosa and theca intra cells (Hurwitz and Adashi, 1993).

Follicular fluid is an exudate of blood plasma supplemented with different protein, glycoproteins and steroids (Gordon,1994). There is relationship between follicular fluids compounds and oocyte quality (Draincourt and Thuel, 1999).Concentration of constituents in follicular fluid may be also related to acquisition of developmental competence.

The objective of the current study was to demonstrate the effects of follicle size in buffalo cumulus morphology, oocyte chromatin configuration, level of apoptosis in cumulus-oocyte complexes as well as measuring progesterone and estradiol 17- $\beta$ in different follicle size. 


\section{MATERIALS \& METHODS}

Apparently normal ovaries of buffalo older than 4 years were obtained from slaughterhouse at Kafr El-Sheikh, Tanta and Cairo. Immediately after slaughtering, the ovaries were transported in physiological saline $(0.9 \% \mathrm{NaCl})$ to cell culture laboratory of Faculty of Veterinary Medicine, Tanta University within $3 \mathrm{~h}$. upon reaching laboratory the ovaries were washed in PBS (phosphate buffer saline). The follicles were isolated and classified according their size into 3 categories: $<3$ (2-3 mm), 3-5 $\mathrm{mm}$ and $>5 \mathrm{~mm}(5-8 \mathrm{~mm})$. Cumulus oocyte complex (COC) were recovered by rupturing the isolated follicles with fresh medium, the follicles were opened and pressed with tweezers and a needle under stereo-microscope in order to observe the release of COCs. COCs were washed twice, and the cumulus morphology of isolated COCs was characterized as compact, slightly expanded (few dispersed), expanded and denuded oocytes. Oocytes with complete, compact multilayered, unexpended cumulus and dark homogenous granulated cytoplasm were used for further manipulation. COCs were either fixed in acetic alcohol for analysis of meiotic configuration at time of recovery or cultured at $38.5 \mathrm{oC}, 5 \% \mathrm{CO} 2$ and $100 \%$ humidified air in maturation medium (TCM-199) (Sigma Chemical Co., Deisenhofen, Germany) plus $20 \%(\mathrm{v} / \mathrm{v})$ heat treated bull serum (Alm et al., 1998) and antibiotic (100 IU penicillin and $100 \mu \mathrm{g}$ streptomycin/ml). Additional granulosa cells were prepared and added at a concentration of $2 \times 106 / \mathrm{ml}$. The granulosa cell preparation was carried out by the method previously described by Lu et al. (1987).

After in vitro maturation for $24 \mathrm{hr}$, the COCs from different sized follicles were carefully denuded from cumulus cells (either mechanically by repeated pipetting or chemically by $0.1 \%$ trypsin) and transferred to Petri-dish containing $0.9 \%$ tri-sodium citrate.

Cumulus cells were examined for apoptosis by TUNEL and oocytes were fixed with acetic alcohol (1: 3 acetic acid and ethanol) and stained with aceto-orcein to evaluate stage of meiotic maturation.

$\overline{\text { Kafr El-Sheikh Vet. Med. J. Vol. } 1 \text { No. } 1 \text { (2003) }}$ 
Based on the nuclear status, oocytes were classified into diplotene or germinal vesicle (immature oocyte), germinal vesicles breakdown, metaphase1, anaphase 1 (oocyte in resumption of meiosis), telophase 1 and metaphase 2 (mature oocyte). Metaphase classified depending on the presence of polar body into early metaphase 2 (included polar body) and late metaphase 2 (with extruded pycnotic polar body).

The percentage of cumulus cells with apoptotic nuclei was estimated according to Torner et al., (2003) using an apoptosis kit (Boehringer-Mannheim). For determination of apoptosis, the cumulus cells were separated, dried on poly-L-lysine coated slide and fixed in $4 \%$ formaldehyde. After fixation the slides were stained with TUNEL reaction mixture and Propidium iodide, embeded and subsequently evaluated by fluorescence microscopy. Condensed chromatin and fragmenting nuclei is a sign for apoptosis (Moley et al., 1998).

Buffalo follicular fluid was collected from visible follicles of different categories. Follicular fluid was aspirated with 20 -gaue needle, the cellular debris was removed from pooled aspirated fluid by centrifugation at $5,000 \mathrm{rpm}$ for $15 \mathrm{~min}$. then stored at $-20 \mathrm{oC}$ till hormonal assay.

Progesterone and estradiol 17- $\beta$ were analyzed by radioimmunoassay according to Burtis and Ashwood (1994).

The obtained data were statistically were analyzed according $\boldsymbol{S A S}$ (1989) System for Windows (release 8.02). Elementary statistics and frequency of table was calculated with the help of the procedures of MEANS and FREQ in SAS/BASE Software.

\section{RESULTS}

A total of 295 cumulus-oocyte complex (COCs) were recovered. Table (1) and figure (1) depicts COCs morphology depending on follicle size, the presence of compact COCs in smaller and medium sized follicles $(<3$ and $3-5 \mathrm{~mm}$ ) were significantly higher than that in large follicles $(>5 \mathrm{~mm})$. On the other hand, slightly expanded COCs (Fig. 2) 
derived from larger follicle (> $5 \mathrm{~mm}$ ) were significantly higher $(57.1 \%)$ than obtain from smaller and medium size follicle (37.3\% and 30.9\%) respectively. In all follicle classes, there was very low number of expanded and denuded COCs recovered. In general, the follicle size affect buffaloes COCs morphology.

Table (1):COC morphology depending on follicle size $(\mathrm{n}=295)$.

\begin{tabular}{|c|c|c|c|c|c|}
\hline \multirow{2}{*}{$\begin{array}{c}\text { Follicle } \\
\text { size }(\mathrm{mm})\end{array}$} & \multirow{2}{*}{$\begin{array}{l}\text { Number } \\
\text { of COC }\end{array}$} & \multicolumn{4}{|c|}{ Cumulus morphology \% } \\
\hline & & Compact & Slightly expanded & Expanded & Denuded \\
\hline$<3$ & 134 & $56.7^{\mathrm{a}}$ & $37.3^{c}$ & 1.5 & 4.3 \\
\hline $3-5$ & 126 & $57.1^{\mathrm{a}}$ & $30.9^{c}$ & 10.3 & 1.6 \\
\hline$>5$ & 35 & $34.3^{b}$ & $57.1^{\mathrm{d}}$ & 8.6 & 0 \\
\hline
\end{tabular}

a:b, c:d $P<0.05$ (computed statistics are based on the asymptotic Chi-square distribution of the likelihood ratio statistic for pair wise liner contrasts within the columns of the table; PROC GENMOD inSAS/STAT)

After characterization of recovered COCs, it was cytologically examined for chromatin configuration at time of recovery. A total of 58 compact COCs were examined. High quality immature oocyte (Fig. 3) with germinal vesicle stage used for IVM were significantly higher in COCs recovered $<3 \& 3-5 \mathrm{~mm}(60.0 \%$ and $70.8 \%)$ follicles than that collected from $>5 \mathrm{~mm}(11.1 \%)$. On contrast higher percentage of oocytes in resumption of meiosis (diaknesis, 'metaphase and anaphase) were collected from $>5 \mathrm{~mm}(77.8 \%)$ follicles than $<3$ and $3-5 \mathrm{~mm}$ (40.0\% and 29.2\%) (Table 2).

Table(2):Chromatin configuration in compact buffalo COC at time of recovery depending follicle size $(n=58)$.

\begin{tabular}{|c|c|c|c|c|}
\hline \multirow[b]{2}{*}{$\begin{array}{l}\text { Follicle } \\
\text { size mm }\end{array}$} & \multirow[b]{2}{*}{$\begin{array}{l}\text { Number } \\
\text { of COC }\end{array}$} & \multicolumn{3}{|c|}{ Chromatin configuration \% } \\
\hline & & $\begin{array}{c}\mathbf{G V} \\
\text { (Immature) } \\
\end{array}$ & $\begin{array}{l}\text { GVBD to Ana (in } \\
\text { resumption of meiosis) }\end{array}$ & $\begin{array}{c}\text { Telol/meta2 } \\
\text { (mature) }\end{array}$ \\
\hline$<3$ & 25 & $15(60.0)^{\mathrm{a}}$ & $10(40.0)^{\mathrm{c}}$ & 0 \\
\hline $3-5$ & 24 & $17(70.8)^{\mathrm{a}}$ & $7(29.2)^{\mathrm{c}}$ & 0 \\
\hline$>5$ & 9 & $1(11.1)_{\mathrm{b}}$ & $7(77.8)^{\mathrm{d}}$ & $1(11.1)$ \\
\hline
\end{tabular}

a:b, c:d $\mathrm{P}<0.05$ (computed statistics are based on the asymptotic Chi-square distribution of the likelihood ratio statistic for pair wise liner contrasts within the columns of the table; PROC GENMOD in SAS/STAT)

$\overline{\text { Kafr El-Sheikh Vet. Med. J. Vol. } 1 \text { No. } 1 \text { (2003) }}$ 
After in vitro maturation of 118 buffalo COCs for $24 \mathrm{hrs}$, chromatin configuration (table 3) showed non-significant difference in M2 (Fig. 4) in COCs derived from all follicles classes. Moreover, there were slightly increase in M2 rate in oocyte drived from follicles $3-5 \mathrm{~mm}(62.8 \%)$ than that derived from $<3 \mathrm{~mm} \&>5 \mathrm{~mm}(46.2 \%$ and $53.4 \%)$. Also no difference was observed in early metaphase 2 (with polar body) and late metaphase 2 (with extruded pycnotic polar body).

Table(3):Metaphase 2 rate in buffalo oocytes 24 after IVM depending on follicle size $(\mathrm{n}=118)$.

\begin{tabular}{|c||c||c|c|c||}
\hline \multirow{2}{*}{\begin{tabular}{c}
\multirow{2}{*}{ Follicle } \\
size mm
\end{tabular}} & \multirow{2}{*}{$\begin{array}{c}\text { Number } \\
\text { of COC }\end{array}$} & \multicolumn{4}{|c|}{ Metaphase II, n (\%) } \\
\cline { 3 - 5 } & & M 2 total & Early M 2/T1 & Late M2 + PB \\
\hline \hline$<3$ & 52 & $24(46.21)$ & $8(33.3)$ & $16(66.7)$ \\
$3-5$ & 51 & $32(62.7)$ & $6(19.0)$ & $26(81.0)$ \\
$>5$ & 15 & $8(53.4)$ & $3(31.0)$ & $5(69.0)$ \\
\hline
\end{tabular}

Table (4) showed that the incidence of apopotosis in the cumulous cells at the time of recovery (Fig. 5) was decreased with increasing follicle size. Values of $0.9 \%, 0.6 \%$ and $0.2 \%$ in cumulus cells collected from $<3 \mathrm{~mm}, 3-5 \mathrm{~mm}$ and $>5 \mathrm{~mm}$ follicular groups respectively, this difference was not statistically significant.

After $24 \mathrm{hr}$ IVM, the incidence of apoptosis in all cumulus was higher after culturing than before (table 4,Figure 6), with significantly increased apoptotic percent in cumulus cells from follicle $3-5 \mathrm{~mm}$ $(24.4 \%)$, which is corresponding to higher metaphase 2 in these categories.

There were no differences in Progesterone concentration in follicular fluid obtained from different sized follicles. In contrary estradiol $17 \beta$ was significantly higher in follicles with $3-5 \mathrm{~mm}$ and $>5 \mathrm{~mm}$ follicle in size $(782.67 \pm 26.84$ and $788.67 \pm 95.71$ respectively) than in follicular fluid from $<3 \mathrm{~mm}$ sized follicle $(682.67 \pm 77.72)$ as shown in Table (5). 
Table(4):Incidence of apoptosis in cumulus cells from buffalo COCs originated from different follicle categories before and after IVM.

\begin{tabular}{|c||c|c||c|c||}
\hline \hline \multirow{2}{*}{$\begin{array}{c}\text { Follicle } \\
\text { size mm }\end{array}$} & \multicolumn{2}{|c||}{ IVM to (time recovery) } & \multicolumn{2}{c||}{ IVM t24 (after IVM 24 h) } \\
\cline { 2 - 5 } & $\begin{array}{c}\text { No. of cumulus cells } \\
\text { (n) counted }\end{array}$ & $\begin{array}{c}\text { Apoptotic } \\
\text { Cells \% }\end{array}$ & $\begin{array}{c}\text { No. of cumulus } \\
\text { cells }\end{array}$ & $\begin{array}{c}\text { Apoptotic } \\
\text { cells \% }\end{array}$ \\
\hline \hline$<3$ & 2000 & 0.9 & 2000 & $4.7^{\mathrm{a}}$ \\
$3-5$ & 1000 & 0.6 & 4000 & $24.4^{\mathrm{b}}$ \\
$>5$ & 1000 & 0.2 & 5000 & $3.5^{\mathrm{a}}$ \\
\hline
\end{tabular}

a:b, $P<0.05$ (computed statistics are based on the asymptotic Chi-square distribution of the likelihood ratio statistic for pair wise liner contrasts within the columns of the table; PROC GENMOD in SAS/STAT)

Table (5):Concentration of progesterone ( $\mathrm{ng} / \mathrm{ml})$ and estradiol- $17 \beta(\mathrm{ng} / \mathrm{ml})$ in follicular fluid from different follicle size.

\begin{tabular}{|c|c|c|}
\hline Follicle size (mm) & Progesterone (ng/ml) & Estradiol $17 \beta(\mathrm{ng} / \mathrm{ml})$ \\
\hline$<3$ & $52.77 \pm 3.81$ & $682.67 \pm 77.22^{\mathrm{a}}$ \\
\hline $3-5$ & $49.56 \pm 1.40$ & $782.67 \pm 26.84^{b}$ \\
\hline$>5$ & $51.80 \pm 9.16$ & $788.67 \pm 95.71^{\mathrm{b}}$ \\
\hline
\end{tabular}

\section{DISCUSSION}

Many reported factors have been affecting in vitro maturation and fertilization. The origin and quality of cumulus oocytes complexes are the most important factor for successful embryo production. Moreover, there is a positive relationship between follicle diameter and developmental competence of obtained oocytes in bovine (Pavlok et al., 1992,1993,1997,Lonergan et al.,1992,1994;Hageman et al.,1999;Heleil et al.,1998,2001). No available reports indicate the influence of follicle size on the developmental competence of buffalo COCs. The present work aimed to study the effect of follicle size, on maturation competence, level of apoptosis in cumulus cells and concentration of progesterone and estradiol-17 $\beta$ in buffalo follicular fluid. 
The morphological classification of COCs depending on of cumulus features would be a routine work for selecting of potential oocytes for in vitro production of embryo (Shioya et al., 1988; Donnay et al., 1995; Alm and Hinrichs, 1996). The result of many reports indicated that compact, complete multilayered cumulus of COCs is considered as criteria for the highest developmental competence in vitro (DeLoose, et al., 1989; Hawk and Wall, 1994). Our finding revealed that more compact COCs were obtained from follicles $<3 \mathrm{~mm}, 3-5 \mathrm{~mm}$.On the other hand the higher percent of slightly expanded COCs was obtained from large follicles (Table 1). In contrast, Lonergan et al. (1992) obtained a more compact COCs in bovine from large follicles (> $6 \mathrm{~mm})$ than small one $(2-6 \mathrm{~mm})(70 \%$ vs. 47\%). Moreover, Heleil (1999); recovered more compact COCs from follicle $>5 \mathrm{~mm}$ than from smaller one $(<5 \mathrm{~mm})$.

On the other hand, the percent of recovered denuded oocytes was found in follicles $<3$ and $3-5 \mathrm{~mm}$, this may be explained on the basis that many follicle more than $2 \mathrm{~mm}$ diameter undergo atresia resulting in heterogeneous population of ovarian follicles (De-Loose et al., 1991 and Pavlok et al., 1992). The morphological variation of buffalo COCs in our finding (table1) may be explained in terms of differences in the stage of growth or degeneration of the complex relative to of follicular growth and atresia (Driancourt, 1991).

The good quality oocytes used for IVM were mostly found in follicles $<3$ and 3-5 $\mathrm{mm}$ in diameter where the meiotic events arrested at germinal vesicle stage (60.8 and 70.8\%), table (2). In contrast to our result Heleil et al. (2001), Torner et al. (2001) observed that oocytes from follicles $<3 \mathrm{~mm}$ were spontaneous and faster on nuclear maturation than oocytes derived from larger follicles than $3 \mathrm{~mm}$. In our result oocyte from large follicles showed higher percent in resumption of meiosis $(77.8 \%)$, this may be attributed to a low number of investigated oocytes or the follicle may be selected to become dominant.

Our finding (table 3) indicates that the COCs from different follicle size show similar maturation-rate (M2) with slight non-significant increase in oocyte from $3-5 \mathrm{~mm}$ follicle. This results come in agreement 
with Tan and Lu, (1990); Yang et al. (1998) and Ocana-Quero et al. (1999). In contrast to our results Pavlok et al. (1992, 1997); Lonergan et al. (1994), Blondin and Sirard (1995); Heleil et al. (2001) who reported that oocyte originated from smaller follicle have low maturation capacity.

Atresia occurs at all stage of follicular development (Hirshfield, 1991). Follicle atresia occurred via apoptosis (Tilly et al., 1991). Apoptosis is physiological regulated form of cell death. (Jolly et al., 1994,Hsu and Hsueh,1997)Our finding indicated that,before maturation, apoptosis level in cumulus cells decreased with increasing follicle size. This may explained on the base of complex relationship between follicular growth,degeneration and atresia. After $24 \mathrm{~h}$ of in vitro maturation, the observed increase of apoptosis (table 4) in cumulus from all follicle sizes were significantly different in cumuli derived from follicle $3-5 \mathrm{~mm}$ than that from follicle $<3 \mathrm{~mm}$ and $>5 \mathrm{~mm}$. The increase apoptosis in cumulus after $24 \mathrm{~h}$ of maturation can be explained as the end of final maturation and differentiation process, which is very important for cumulus expansion and loosening mechanism in process of oocyte maturation. In agreement with our finding Hinriches (1996) observed strong correlation between cumulus expansion and follicular atresia. On the other hand, Driancourt (1991), Pavlok et al. (1992) observed that many follicles $>1 \mathrm{~mm}$ undergoes atresia. In cow Heleil, (1999) found a increased of apoptosis after IVM from all COCs derived from follicles 2$8 \mathrm{~mm}$ in diameter but was lowest in cumulus cell nuclei of COCs from follicles larger than $5 \mathrm{~mm}$ this was in agreement with our result. While Torner et al, (1998 and 2003) observed that, after IVM there was highly increased in apoptosis in cumuli cells specially of COCs obtained from ovaries from non pregnant she-camel.

Progesterone concentration (ng/ml), not influenced by follicle size. On other hand a significant increased in estradiol-17 $\beta$ in follicular fluid was obtained from follicle $3-5 \mathrm{~mm}$ and $5-8 \mathrm{~mm}(782.67 \pm 26.84,788.67 \pm$ $95.71)$ than in $<3 \mathrm{~mm}(682.67 \pm 77.2)$. This can be explained that follicles up to $3 \mathrm{~mm}$ in diameter gave gonadotropin receptors on their granulose cells and this leads to activation of steroidogenesis, results in increased 
estradiol concentration. Similar results were obtained by Grimes $\boldsymbol{e t}$ al. (1987) who concluded that concentration of steroid in FF or binding capacity of granulosa for gonadotrophins steroids which indices of follicular function and also indices for follicular atresia. Both progesterone and estradiol concentration were positively correlated to the volume of the follicle. Irland and Roche (1982) observed relationship between progesterone and estradiol concentration and follicular diameter ranging from 15 to $20 \mathrm{~mm}$. He demonstrated strong positive correlation between follicular volume and diameter which is related to their physiological function. Numerous studies have generally found that oocytes obtained fromfollicle rich in progesterone has better quality (Fishel et al., 1983; Botero and Ruiz et al. 1984). Although some other studies failed to confirm these results (Tarlatzis et al., 1993; Suchamek et al., 1994). In contrast there is general agreement between all studies for the lack of correlation between progesterone concentration in follicular fluid and oocyte quality (Yding, Anderson,1990 and Suchanek et al., 1994).

In conclusion, follicle sizes in buffalo play an important role in selection of oocyte for IVM. More than $50 \%$ of recovered buffalo COCs from follicles 2-5 mm used for IVM. Follicle size influence distribution of COC, morphology but not maturation capacity after $24 \mathrm{~h}$ of IVM. There were a correlation between follicle size and level of apoptosis of cumulus and also concentration of estradiol $17 \beta$ in buffalo follicular fluid. This would help in production of embryos from ovaries obtained from abattoir to rescue the precious germ plasm that is lost by slaughtering.

\section{Acknowledgements:}

The authors thank the DAAD in Germany for supporting this work. This work is done through cooperation between Faculty of Veterinary Medicine, Tanta University, and Institute of Biology of Farm Animals, 18196 Dummerstorf, Germany. 
Heleil,B.,et.al.

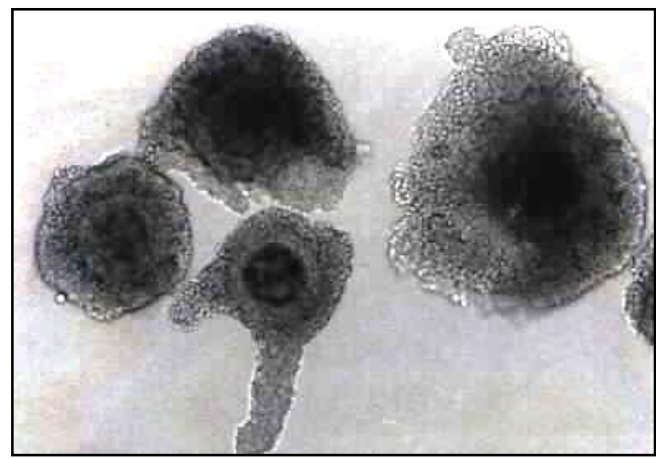

Fig. (1) Compact COCs

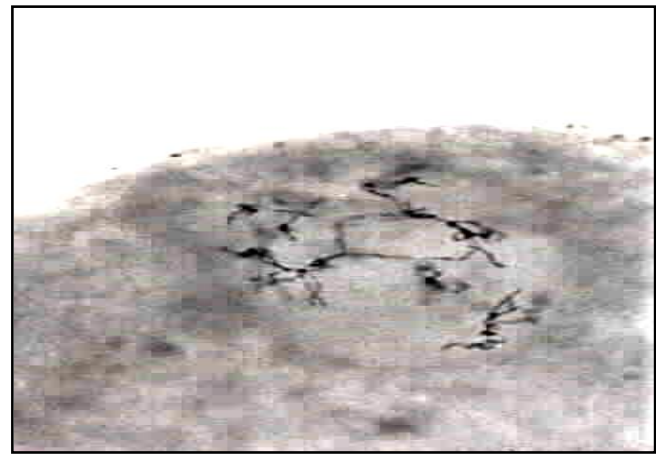

Fig. (3): Oocyte with germinal vesicle stage

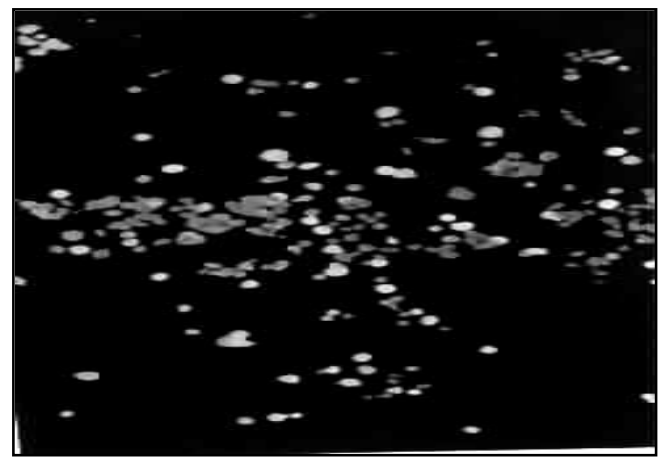

Fig. (5): Apoptosis in cumulus cell at the time of recovery

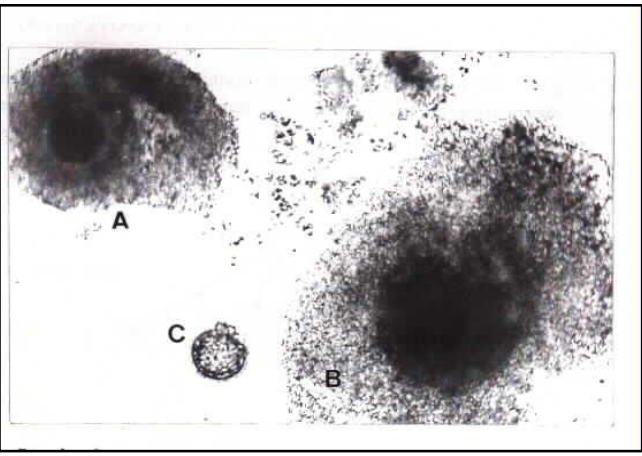

Fig. (2) A: compact COCs, B: Slightly expanded, $\mathrm{C}$ : denuded

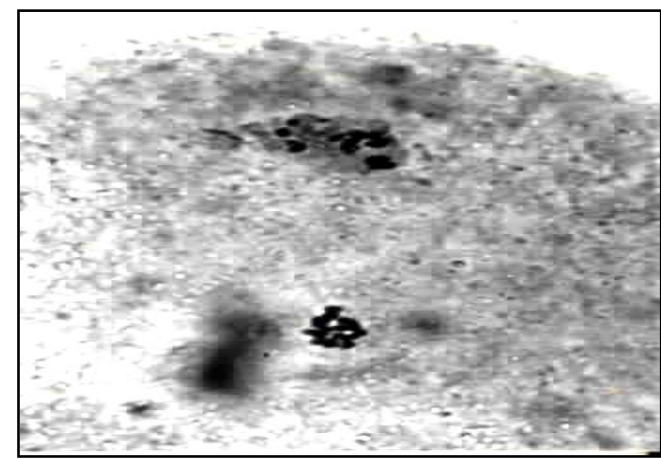

Fig. (4) Oocyte with metaphase 2 with extruded polar body

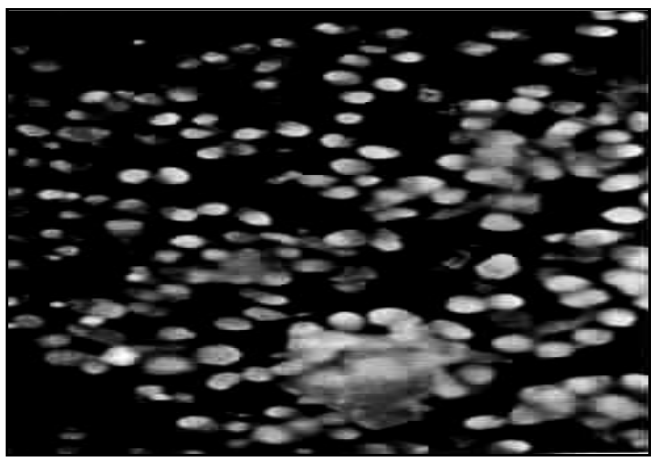

Fig. (6): Apoptosis in cumulus cell after IVM.

$\overline{\text { Kafr El-Sheikh Vet. Med. J. Vol. } 1 \text { No. } 1 \text { (2003) }}$ 


\section{REFERENCES}

- Alm, H. and Hinrichs, K. (1996). Effect of cycloheximide on nuclear maturation of horse oocytes and its relation to initial cumulus morphology. J. Reprod. Fertile. 107, 215-220.

- Alm, H.; Torner, H.; Ruzmina, T. and Kanitz, W. (1998). Influence of prolactin and cAMP on maturation and developmental competence of bovine oocytes in vitro. Theriogenology, 304 (Abstract).

- Blondin, P. and Sirard, M.A. (1995). Oocyte and follicular morphology as determining characteristics for developmental competence in bovine oocytes. Mol. Reprod. Dev. 41, 54-62.

- Boteroruiz, W.; Laufer, N.; deCherney, A.H.; Polan, M.L.; Hase Hine, F.P.and Behhrman, H.R. (1984). The relationship between follicular fluid steroid concentration successful fertilisation of human oocytes in vitro. Fert. Ster. $41 ; 820-826$.

- Burits, C.A. and Ashwood, E.R. (1994). Titez textbook clinical chemistry. $2^{\text {nd }}$ edit. W.B. Sounders Company Philadelphia. p. 1863.

- DeLoos, F.; Kastrop, P.; Vanmaurik, P.; Vanbeneden, T.H. and Kruip, T.A.M. (1991). Heterologous cell contact and metabolic coupling in bovine cumulus oocyte complexes. Mol Reprod. Deve. 28, 255-259.

- DeLoos, F.; Van Villet C.; Van Maurik, P.and Kruip, T.A.M. (1989). Morphology of immature bovine oocytes. Theriogenology, 25: 197-204.;

- Donnay, I.; Van Langendonckt, A.; DeRoover, R.; Massip, A.and Dessy, F. (1995). Quality and further development of cattle oocytes obtained after ultrasound-guided or direct visualization of ovarian. 11 e Reunion A.E.T.E.Hannover, 8-9 September, Kongr. Ber. p. 164 (Abstr.)

- Driancourt,M.A.(1991).Follicular dynamics in sheep and cattle.Theriogenology, 35, 55-75.

- Driancourt, M.A. and Thuel, B. (1998): Relationships between quality and follicle function.Reprod.Dom.Anim.33, 113-117. 
- Fishel, S.B.; Edwards, R.G. and Weilters, D.E. (1983). Follicular steroids as prognosticator of successful fertilization of human oocytes in vitro. J. Endocr. 99: 335-344.

- Gordon, J. (1994). Laboratory production of cattle embryos. Biotechnology in Agriculture No. 11 CAB International, Wullingford.

- Grimes,R.W.;Matton,P.and Ireland,J.J.(1987)A comparison of histological and non-histological indices of atresia and follicular function. Biol. Reprod. $37,82-88$.

- Hageman, L.J. (1999). Influence of the dominant follicle on oocytes from subordinate follicles. Theriogenology, 51, 449-459.

- Hawk,H.W.;Wall,R.J.(1994). Improved yields of bovine blastocysts form in vitro produced oocytes.I.Selection of oocytes and zygotes. Theriogenology, 41, 1571-1583.

- Heleil, B. (1999). Untersuchungen Zur meiotischen Endreifungvon bovine cumulus-oozyten-komplexen in Abhaengigkeit von der Follike grosse. Lepizig University. PH Thesis.

- Heleil, B.; Alam; H.; Kuzmina, T.;Tomek, W.; Greising,T. and Torner, H. (2001). Physiological status of bovine cumulus-oocyte-complexes-basic for embryo production in vitro. Arch-Tierzuch (Suppl.) 91-93.

- Hinrichs, K.(1996). Manipulation of oocyte maturation in vitro. Arch. Tierz, Dummerstorf 39 (Special issue) pp. 43-50.

- Hirshfield, A.N. (1991). Development of follicles in mammalian ovary. Int. Rev. Cytol. 124, 43-101.

- Hsu, S.Y. and Hsueh, A.J.W. (1997). Hormonal regulation of apoptosis: an ovarian perspective. Trend. Endocrine. Metab. 8, 207-213.

- Hurwitz, A.; Adashi, E.Y. (1993). Ovarian follicular atresia as an apoptotic process. In: Adashi E.Y., Leung PCK (eds.), and The ovary. Raven Press, New York, pp. 473-485. 
- Ireland,J.J.and Roche,J.F.(1982). Development of antral follicles in cattle after prostaglandin-induced luteolysis: Changes in serum hormones, steroids in follicular fluid,and gonadotropin receptors.Endocrinology 11,2077-2086.

- Jolly, P.D.; Tisdall, D.J.; Heath, D.A.; Lun, S. and McNatty, K.P. (1994). Apoptosis in bovine granulosa cells in relation to steroid synthesis, cyclic adenosine 3',5'-monophosphate response to follicle-stimulating and luteininzing hormone and follicular atresia. Biol. Reprod. 51, 934-944.

- Kruip,T.A.M.and Dielman,S.J.(1982). Macroscopic classification of bovine follicles and its validation by micromorphological and steroid biochemical procedures. Reprod. Nutr. Dev. 22, 465-473.

- Lonergan, P.;Monaghan,P.;Rizos,D;Boland, M.P. and Gordon, I. (1994). Effect of follicle size on bovine oocyte quality and developmental competence following maturation, fertilization and culture in vitro. Mol. Reprod. Dev. 37, 48-53.

- Lonergan, P.; Sharif, H.; Monaghan, P.; Wahid, W.; Gallagher, M. and Gordon, I. (1992). Effect of follicle size on bovine oocyte morphology and embryo yield following maturation, fertilization and culture in vitro. Theriogenology, 37, 248 (Abstr.).

- Lu, K.H.; Gordon, I.; Gallagher, M. and McGoverin, H.(1987). Pregnancy established in cattle by transfer of embryos derived from in vitro fertilization of oocytes matured in vitro. Vet. Rec. 121, 259-260.

- Misra, A.K.;Joshi,B.V.;Agrawala, P.L.;Ksiraj,R.; Sivaiah, S.; Rangareddi, N.S. and Sidiqui, M.U. (1991). Multiple ovulation and embryo transfer in Indian buffaloes (Bubalus bubalis). Theriogenology, 33: 1131-1142.

- Moley, K.H.; Chi, M.M.; Knudson, C.M.; Korsmeyer, S.J. and Muekler, M.M. (1998). Hyperglycemia induces apoptosis in pre-implantation embryo through cell death effector pathway. Nature Medicine 4, 1421-1424.

- Pavlok, A.; Kalab, P. and Bobak, P. (1997). Fertilization competence of bovine normally matured or aged oocytes derived from different antral follicles: Morphology, protein synthesis,111 and MBP kinase activity. Zygote 5, 1-12. 
- Pavlok, A.; Kopency, V.; Lucas-Han, A. and Niemann, H. (1993). Transcriptional activity and nuclear ultrastructure of 8-cell bovine embryos developed by in vitro maturation and fertilization of oocytes from different growth categories of antral follicles. Mol. Reprod. Dev. 35, 233-243.

- Pavlok, A.; Lucs-Hahn, A. and Niemann, H. (1992). Fertilization and development competence of bovine oocytes derived from different categories of antral follicles. Mol. Reprod. Dev. 31, 63-67.

- SAS Institute Inc. (1989). SAS/STAT User's Guide, Version 6, Fourth Edition, Volume, 1, Carry, NC: SAS Institute Inc.

- Shioya, Y.; Kuwayama, M.;Fukushima, M. and Iwasaki, S. (1988).In vitro fertilization and cleavage capability of bovine follicular oocytes classified by cumulus cells and matured in vitro. Theriogenology, 30, 489-496.

- Sirard, M.A. and Blondin,P. (1996). Oocyte maturation and IFýVF in cattle. Anim. Reprod. Sci. 42: 417-426.

- Snedecor, G.W. and W.G. Cochran (1999). Statistical Methods, $9^{\text {th }}$ Ed., Oxford Univ.

- Suchanek, E.; Simunic, V.; Juretic, D. and Grizely, V. (1994). Follicular fluid contents of hyalouronic acid, follicle stimulating hormone and steroids relative to the success of in vitro fertilization of human oocytes. Fert. Ster. 62: 347-352.

- Tan, S.J. and Ku, K.H.(1990). Effects of different oestrous cycles, stages of ovaries and sizes of follicles on generation of IVF in early bovine embryos. Theriogenology 33, 335 (Abstr.).

- Tarlatiz, B.C.; Pazaitou, K.; Bili, H.; Bontis, J.; Papadimas, J.; Lagos, S.; Spanos, E. and Mantalenkis, S. (1983). Growth hormone, oestradiol, progesterone and testosterone ovarian stimulation with various regimes for assisted reproduction. Hum. Reprod. 50, 111-119.

- Tilly, J.L.; Kowalski, K.I.; Johnson, A.L. and Hsueh, A.J.W. (1991). Involvement of apoptosis in ovarian follicular atresia and postovulatory regression. Endocrinology 129, 2799-2801. 
- Torner, H.; Heleil, B.;Ghoenim,I.M.;Sresen,V.;Fattouh, E.M. and (1998). Influence of pregnancy on morphology of cumulus-oocyte-complexes in the dromedary Camel. Advances in Ethology, 33 (Suppl.) 74 (Abstr.).

- Torner, H.; Heleil, B.; Alm, H., Ghoenim, I.M.; Sresen, V.; Kanitz, W. and Fattouh, E.M. (2003). Changes in cumulus-oocyte-complexes of pregnancy and non- pregnancy camels (camelus dromedaries) during maturation in vitro. Theriogonology, 8903:1-11.

- Torner, H.; Kubelka, M.; Heleil, B.; Tomek W, Alm, H and Kuzmina, T. (2001). Dynamic of meiosis and protein kinase activities in bovine oocytes correlated to prolactin treatment and follicle size. Theriogenology, 55: 885-899.

- Totey, S.M.; Daliiri, M.; Apparao, K.B.C; Pawshe, C.H.; Taneja, M. and Chilar, R.S. (1996). Differential cleavage and developmental rates and their correlation with cell number and sex ratios in buffalo embryos generated in vitro. Theriogenology, 15: 531-533.

- Totey, S.M.; Singh, G.; Tanja, M.; Pawshe, C.H and Talwar, G.P. (1992). In vitro maturation, fertilization and development of follicular oocytes from buffalo (Bubalus bubalis). J. Reprod. Fertil., 95: 597-607.

- Yding-Anderson, C. (1990). Levels of steroid binding proteins and steroids in human preovulatory follicular fluid and serum as predictors of success of in vitro fertilization-embryo transfer treatment. J. Clin. Endocr. Metab. 71; 1375-1381. 


$$
\begin{aligned}
& \text { تأثثير حجم الجريبات على السحب المتر اكمة المركبة }
\end{aligned}
$$

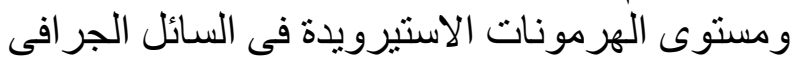

$$
\begin{aligned}
& \text { للجاموس0 }
\end{aligned}
$$

بسيونى هليل1-هلموت تورنر 2- شوقى عبد الهادى 3-هانيلورا ألم² وإلسيد فتوح1 1

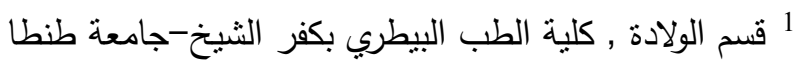
2 معهد البحوث البيولوجية لحيوانات المزرعة ,ديمرستورف 18196 ألمانيا

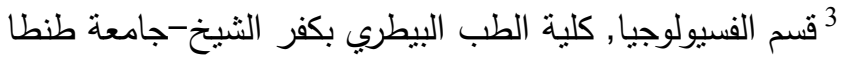

استهدفت هذه الدراسـة تأثنير حجم الجريبات علي تثكيل السحب المتراكمة للجاموس وتتكيل الكرومـاتين ومعدل الأبيتوزس وكذللك معدل هرمسون البروجيسترون والإستراديول 17-ب فئي في السـائل الحويصلي للأحجام المختلفة.

تم تجميع 295 جريب من مبايض مجمعة مباشرة بعد ذبح الجاموس ، قسمت الي 3 مجموعات

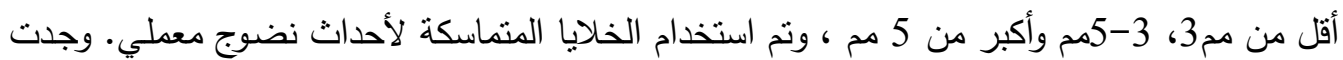

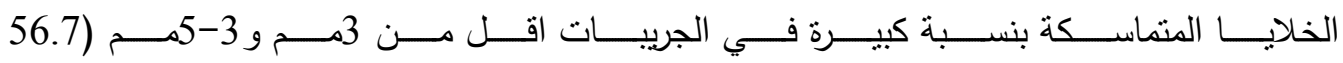
و 57.1\% 5تتابعة).

بالنسبة لتتكيل الكرومـاتين عند وقت الاسترداد قد ثنبت عند مستوي الجريبـة المتتبتة بنسبة

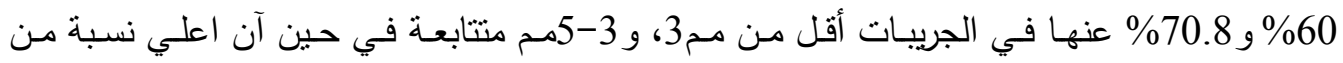
استئناف الانقسام الميوزى وجدت في الحويصلات الكبيرة بنسبة 77.8\%

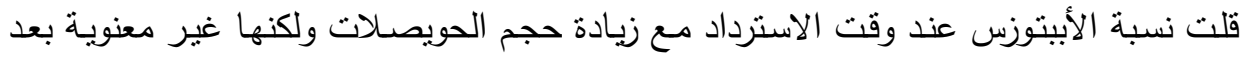

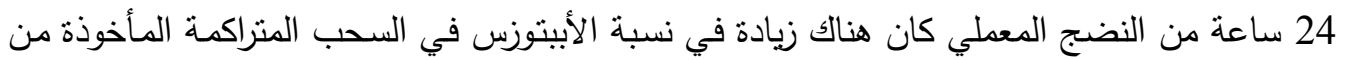
الجريبات 3-5 مم عنها في أقل من 3مم ، وأكبر من 5مد.

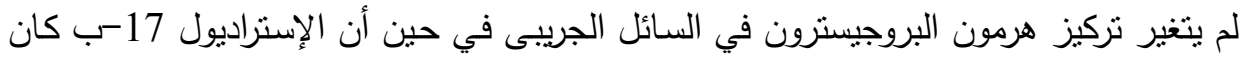

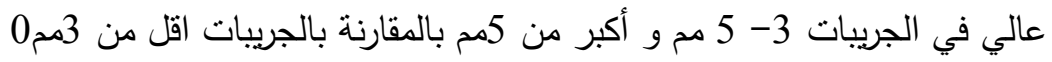

